\title{
Insulin regulation of glucose and lipid metabolism in massive obesity
}

\author{
S. Del Prato ${ }^{1}$, G. Enzi ${ }^{2}$, S. Vigili de Kreutzenberg ${ }^{1}$, G. Lisato $^{1}$, A. Riccio ${ }^{1}$, L. Maifreni ${ }^{1}$, E. Iori ${ }^{1}$, F. Zurlo ${ }^{2}$, G. Sergi ${ }^{2}$ \\ and A. Tiengo ${ }^{1}$ \\ ${ }^{1}$ Unit of Metabolic Diseases, and ${ }^{2}$ Regional Center for the Study of Obesity, University of Padova, Italy
}

\begin{abstract}
Summary. Eight obese patients and 12 normal individuals underwent a euglycaemic insulin clamp (20 and $40 \mathrm{mU}$. $\mathrm{m}^{2-1} \cdot \mathrm{min}^{-1}$ ) along with continuous infusion of $3{ }^{-3} \mathrm{H}$-glucose and $1{ }^{14} \mathrm{C}$-palmitate and indirect calorimetry. Basal plasma glucose concentration $(4.7 \pm 0.3$ vs $4.4 \pm 0.2 \mathrm{mmol} / 1)$ was similar in the two groups, whereas hepatic glucose production was slightly higher in obese individuals $(1.11 \pm 0.06$ vs $0.84 \pm 0.05 \mathrm{mmol} / \mathrm{min}$ ) in spite of higher plasma insulin levels $(17 \pm 2$ vs $6 \pm 1 \mathrm{mU} / \mathrm{l} ; p<0.01)$. Insulin inhibition of hepatic glucose production was impaired in obese subjects. Glucose disposal by lean body mass was markedly reduced both at baseline $\left(11.7 \pm 1.1\right.$ vs $\left.15.6 \pm 0.6 \mu \mathrm{mol} \cdot \mathrm{kg}^{-1} \cdot \mathrm{min}^{-1} ; p<0.05\right)$ and during clamp $(15.0 \pm 1.1$ vs $34.4 \pm 2.8$ and $26.7 \pm 3.9$ vs $\left.62.2 \pm 2.8 \mu \mathrm{mol} \cdot \mathrm{kg}^{-1} \cdot \mathrm{min}^{-1} ; p<0.01\right)$ Oxidative $(12.2 \pm 1.1$ vs $17.8 \pm 1$ and $16.1 \pm 1.1$ vs $51.1 \pm 1.7 \mu \mathrm{mol} \cdot \mathrm{kg}^{-1} \cdot \mathrm{min}^{-1}$; $p<0.05-0.002)$ and non-oxidative glucose metabolism ( $3.9 \pm 1.1$ vs $15.0 \pm 2.8$ and $12.8 \pm 3.3$ vs $38.3 \pm 2.2 \mu \mathrm{mol}$. $\left.\mathrm{kg}^{-1} \cdot \min ^{-1} ; p<0.01-0.001\right)$ were impaired. Basal plasma concentrations of non-esterified fatty acids $(635 \pm 75$ vs $510 \pm 71 \mu \mathrm{mol} / \mathrm{l})$ and blood glycerol $(129 \pm 17$ vs $56 \pm 5 \mu \mathrm{mol} / 1 ; p<0.01$ ) were increased in obese patients. Following hyperinsulinaemia, plasma non-esterified fatty acids ( $244 \pm 79$ vs $69 \pm 16$ and $140 \pm 2$ vs $36 \pm 10 \mu \mathrm{mol} / 1 ; p<0.01$ ) and blood glycerol levels ( $79 \pm 20$ vs $34 \pm 6$ and $73 \pm 22$ vs $29 \pm 5 \mu \mathrm{mol} / 1 ; p<0.01)$ remained higher in obese subjects.
\end{abstract}

Baseline non-esterified fatty acid production rate per $\mathrm{kg}$ of fat body mass was significantly larger in normal weight subjects (37.7 \pm 6.7 vs $14.0 \pm 1.8 \mu \mathrm{mol} / \mathrm{l} ; p<0.01)$ and insulin inhibition was reduced in obese patients $(-41 \pm 9$ vs $-74 \pm 3$ and $-53 \pm 11$ vs $-82 \pm 3 \% ; p<0.05)$. Basal plasma non-esterified fatty acid utilization by lean body mass was similar in the two groups $\left(9.8 \pm 0.9\right.$ vs $\left.8.8 \pm 2.0 \mu \mathrm{mol} \cdot \mathrm{kg}^{-1} \cdot \mathrm{min}^{-1}\right)$, whereas during clamp it remained higher in obese patients $(6.0 \pm 1.2$ vs $2.8 \pm 2.5$ and $4.9 \pm 1.3$ vs $1.5 \pm 0.6 \mu \mathrm{mol}$. $\left.\mathrm{kg}^{-1} \cdot \min ^{-1} ; p<0.1-0.05\right)$. Lipid oxidation was higher in obese individuals in spite of hyperinsulinaemia $(3.7 \pm 0.3$ vs $2.4 \pm 0.4$ and $2.3 \pm 0.4 \mathrm{vs} 0.9 \pm 0.3 \mu \mathrm{mol} \cdot \mathrm{kg}^{-1} \cdot \mathrm{min}^{-1} ; p<0.05$ $0.02)$. An inverse correlation was found between lipid oxidation and glucose oxidation $(r=0.82$ and $0.93 ; p<0.001)$ and glucose utilization $(r=0.54$ and $0.83 ; p<0.05-0.001)$ both in obese and control subjects. A correlation between lipid oxidation and non-oxidative glucose metabolism was present only in normal weight individuals $(r=0.75 ; p<0.01)$. We conclude that in obesity all tissues (muscles, liver, and adipose tissue) are resistant to insulin action. Insulin resistance involves glucose as well as lipid metabolism.

Key words: Obesity, insulin, glucose, non-esterified fatty acids, glucose turnover, non-esterified fatty acid turnovers.
Insulin resistance is a universal finding in obesity. Plasma insulin concentration in the basal state and following oral glucose load are commonly elevated in obese patients. Recently, the glucose clamp technique has allowed the quantification of the defect in insulin action. Muscle is apparently the primary site of insulin resistance. In vitro studies have shown that insulin resistance is associated with both receptor and post-receptor alterations. In vivo, the construction of a dose response curve of insulin for glucose uptake has also led to the conclusion that receptor and post-receptor defects of insulin action coexist in obese patients [1,2]. Even though there is universal agree- ment regarding the impaired ability of insulin to promote glucose utilization more controversy exists with respect to insulin action on lipid metabolism. In spite of increased plasma insulin concentration, plasma non-esterified fatty acid (NEFA) levels can be elevated in obese subjects [3, 4]. This would suggest the existence of an impaired ability of insulin to regulate NEFA metabolism. It is also possible that the higher plasma concentration of NEFA is a direct consequence of a larger amount of adipose tissue. The progressive accumulation of fat in obese patients would imply a normal antilipolytic activity of insulin. Studies carried out in adipocytes from obese individuals are appar- 
ently in agreement with this interpretation [5]. Using the forearm technique, Rabinowitz et al. [6] have shown that insulin action on NEFA release from adipose tissue is not altered. More recently, Howard et al. $[7,8]$ reported in a group of obese individuals that insulin-induced reduction in plasma NEFA level was normal or only marginally impaired. On the other hand, in vitro studies have provided evidence that insulin-mediated glucose metabolism in adipocytes from obese subjects is reduced due to a low number of receptors, and glucose transporters [1,2]. Bakir and Jarret [9] reported that constant infusion of insulin in obese subjects is associated with a fall in plasma NEFA concentration that was $51 \%$ lower than in normal weight subjects. Abnormalities in plasma NEFA utilization could also contribute to the rise in plasma NEFA concentrations. A reduced plasma clearance rate has in fact been reported in obese patients [10].

Besides evaluating the possible extension of insulin resistance to NEFA metabolism, the understanding of concurrent effects of insulin on glucose and lipid metabolism has pathophysiologic implications. It has been observed that the so called Randle cycle may be operative in vivo [11]. According to this glucose-NEFA cycle, an increased NEFA oxidation can reduce glucose oxidation, and, in turn, reduce total glucose utilization [12]. A limited ability of insulin to restrain lipolysis can contribute to increased plasma NEFA flux and therefore can activate the Randle cycle to generate a condition of insulin resistance at the level of peripheral tissues. The present study was designed to investigate simultaneously the regulation of glucose and NEFA metabolism by physiologic plasma insulin concentrations in obese individuals.

\section{Subjects and methods}

\section{Subjects}

Eight obese patients and 12 normal subjects participated in the study. Clinical features and anthropometric measures are given in Table 1. Body weight, body mass index and relative ideal body weight of obese subjects were on average twice as high as in the control individuals. Duration of obesity was more that 10 years. In all subjects body composition (Table 1) was calculated according to Hume and Weyers' formula [13]. No patient met the criteria for the

Table 1. Clinical and anthropometric parameters of the study population

\begin{tabular}{lcc}
\hline & Control subjects & Obese subjects \\
\hline$n$ & 12 & 8 \\
Sex (m/f) & $10 / 2$ & $5 / 3$ \\
Age (Years) & $32 \pm 3$ & $36 \pm 4$ \\
Height $(\mathrm{m})$ & $1.76 \pm 0.04$ & $1.67 \pm 0.05^{\mathrm{a}}$ \\
Body weight & $77 \pm 31$ & $127 \pm 8$ \\
Body mass index $\left(\mathrm{kg} / \mathrm{m}^{2}\right)$ & $24 \pm 1$ & $47 \pm 2^{\mathrm{a}}$ \\
\% of ideal body weight & $104 \pm 2$ & $198 \pm 9^{\mathrm{a}}$ \\
Lean body mass $(\mathrm{kg})^{\mathrm{b}}$ & $61 \pm 2$ & $74 \pm 6^{\mathrm{a}}$ \\
Fat body mass $(\mathrm{kg})$ & $16 \pm 1$ & $53 \pm 4^{\mathrm{a}}$ \\
Body surface area $\left(\mathrm{m}^{2}\right)$ & $1.9 \pm 0.1$ & $2.3 \pm 0.1^{\mathrm{a}}$ \\
Fasting plasma glucose $(\mathrm{mmol} / \mathrm{l})$ & $4.4 \pm 0.2$ & $4.7 \pm 0.3$ \\
Fasting plasma insulin $(\mathrm{mmmol} / \mathrm{l})$ & $6 \pm 1$ & $17 \pm 2^{\mathrm{a}}$ \\
\hline
\end{tabular}

${ }^{\mathrm{a} p}<0.05$ or less; ${ }^{\mathrm{b}}$ according to Hume's formula [13] diagnosis of diabetes [14] and no family history for diabetes was present. All subjects had normal blood tests for liver, renal, and endocrine function. All subjects consumed a weight-maintaining diet consisting of at least $250 \mathrm{~g}$ of carbohydrate per day for one week before the study. Protocol was approved by local the Ethical Committee. The purpose, nature, and potential risks of the study were explained to all subjects and their informed consent was obtained before their participation in the experimental protocol.

\section{Euglycaemic insulin clamp}

Following an overnight fast, a euglycaemic clamp study [15] was carried out in all subjects. On the morning of the study, three superficial veins of the forearm were cannulated. An indwelling catheter was inserted in a superficial vein of the arm for test substance infusions. A second cannula was retrogradely inserted into a wrist vein of the contralateral arm for blood sample drawing. The hand was placed into a heated box $\left(70^{\circ} \mathrm{C}\right)$ to achieve arterialization of venous blood. The catheter was kept patent by an infusion of $0.9 \% \mathrm{NaCl}$ solution. Before sampling, the first ml of blood was discarded. Subjects were connected to an artificial endocrine pancreas (Biostator CGIIS Miles, Cavenago Brianza, Italy) through a third teflon catheter for min by min determination of blood glucose concentration. Following $2 \mathrm{~h}$ tracer equilibration (see below) and collection of basal blood samples, a stepwise insulin infusion $\left(20\right.$, and $\left.40 \mathrm{mU} \cdot \mathrm{m}^{2-1} \cdot \mathrm{min}^{-1}\right)$ was started. Each rate of insulin (Actrapid HM, Novo Industri A/S. Copenhagen, Denmark) infusion was primed and maintained constantly for $110 \mathrm{~min}$ [15]. During insulin clamp studies, the plasma glucose concentration was measured on a min by min basis and a $20 \%$ dextrose infusion was automatically adjusted by the artificial endocrine pancreas to maintain the plasma glucose level constant at basal value [16].

\section{Glucose turnover}

A primed $(25 \mu \mathrm{Ci})$ continuous $(0.25 \mu \mathrm{Ci} / \mathrm{min})$ infusion of $3-{ }^{3} \mathrm{H}$-glucose (Amersham, Bucks, UK) was started 120 min before the insulin clamp study, and maintained until the end of experimental protocol. Blood was drawn at $5 \mathrm{~min}$ intervals during the last $30 \mathrm{~min}$ of the equilibration period for determination of basal plasma glucose specific activity. During the insulin clamp study, blood samples were obtained every 15 min until the last 30 min of each insulin step, when blood samples were collected at $10 \mathrm{~min}$ intervals. In all subjects, plasma specific activity of glucose was constant (coefficient of variation $<10 \%$ ) at the end of the equilibration period.

\section{Non-esterified fatty acid turnover}

Simultaneous to the beginning of the tritiated glucose infusion, a constant infusion of albumin-bound $1{ }^{14} \mathrm{C}$-palmitate $(0.1 \mu \mathrm{Ci} / \mathrm{min})$ was begun. This infusion lasted until the end of the glucose clamp study. Labelled palmitate was supplied in toluene. Following drying under nitrogen flow, it was conjugated to human serum albumin (final concentration $1.5 \%$ ). Blood samples were collected at 5$10 \mathrm{~min}$ intervals during the last $30 \mathrm{~min}$ of the equilibration period and during the last $30 \mathrm{~min}$ of each insulin plateau. In all three periods the coefficient of variation for NEFA specific activity was $<10 \%$.

\section{Respiratory gas exchange measurements}

Indirect calorimetry (MMC Horizon Systems, Beckman Inc., Fullerton, Calif., USA) was used in 6 out of the 8 patients and in 8 out of the 12 normal subjects to determine the rate of glucose and lipid oxidation. A 40 min measurement was performed in the basal state and at the end of each insulin clamp step. Briefly, a transparent ventilated hood was placed over the head of the subject and made airtight around the neck. A slight negative pressure was maintained in the 
hood to avoid loss of expired air. Ventilation was measured by dry gas meter, air content of $\mathrm{O}_{2}$ and $\mathrm{CO}_{2}$ was measured by polarographic and undispersive infra-red (NDIR) analysis techniques respectively. Timed urine collections were obtained prior to and during the glucose clamp studies.

\section{Analytic determination}

Plasma glucose concentration was determined by the glucose oxidase method on a glucose analyser (Beckman Instruments., Fullerton, Calif., USA). Determination of plasma specific activity of tritiated glucose was performed according to standard techniques [17]. Plasma insulin concentration was assessed by specific RIA [18]. Plasma NEFA and blood glycerol levels were measured by a fluorometric method as previously described [16]. Urinary nitrogen concentration was determined by the method of Kjeldahl [19]. For determination of ${ }^{14} \mathrm{C}-\mathrm{NEFA}$ specific activity, $1.5 \mathrm{ml}$ of plasma was extracted with $10 \mathrm{ml}$ Dole's solution [20]. NEFA were isolated from the lipid phase using $0.02 \mathrm{~N} \mathrm{NaOH}$ and re-extracted after acidification with heptane. The heptane extraction was repeated three times. Recovery of radioactivity in the heptane phase was $>80 \%$. Extracts were dissolved in scintillation liquid and counted in a Packard Tricarbon Scintillation Counter (model 320, Packard Instruments Inc., Downer Grove, Ind., USA) using external standard to correct for efficiency. Quenching correction was performed automatically.

\section{Calculations}

Body composition. The formula proposed by Hume and Weyers [13] was used to calculate total body water (TBW):

TWB in males $=(0.2968 \times \mathrm{kg})+(0.1948 \times \mathrm{cm})-14.0129$

TBW in females $=(0.1838 \times \mathrm{kg})+(0.3446 \times \mathrm{cm})-35.2701$

Lean body mass (LBM) was then calculated by dividing TBW by 0.73 , since the body contains approximately $73 \%$ water [21]. Fat body mass (FBM) was calculated as the difference between body weight and LBM. In a different group of 20 subjects we have calculated that estimation of LBM by the above formulas is highly correlated with that obtained by using tritiated water $(r=0.93 ; p<0.001)$.

Whole body glucose metabolism. The last $40 \mathrm{~min}$ of each step of insulin infusion (70-110 and 180-220 min, respectively) were used for calculation of insulin-mediated glucose metabolism. Glucose uptake. was computed as the sum of the average rate of exogenous glucose infusion plus residual hepatic glucose production $(15,22)$. Glucose utilization is expressed per unit $(\mathrm{kg})$ of LBM.

Hepatic glucose production (HGP). In the basal state HGP was calculated according to isotopic dilution formula [17]. After administration of insulin, a non-steady state condition in glucose specific activity occurs. Therefore, a non-steady state approach was used [17]. The integrated rate of exogenous glucose infusion over a $20 \mathrm{~min}$ interval was subtracted to Ra during the same time period to estimate HGP. Negative values for HGP were assumed equal to zero. In the text, HGP values refer to the mean rate during the last $40 \mathrm{~min}$ of each insulin infusion step. In the basal state, HGP meets glucose utilization. However, the basal rate of HGP is mainly regulated by portal insulin concentration and liver sensitivity to insulin [23], while basal glucose uptake is the result of glucose utilization in insulin- and noninsulin-mediated glucose metabolism [24]. Therefore, we have chosen to express HGP as the total amount of glucose produced per $\mathrm{min}(\mathrm{mmol} / \mathrm{min})$, and glucose utilization as utilization rate per unit of lean body mass per unit of time $\left(\mu \mathrm{mol} \cdot \mathrm{kg} \mathrm{LBM}{ }^{-1} \cdot \mathrm{min}^{-1}\right)$.

NEFA tumover rate. Plasma labelled palmitate has been shown to represent other plasma NEFA and to reflect whole body plasma NEFA kinetics [25-27]. Plasma NEFA concentration and specific activity were measured during the last $30 \mathrm{~min}$ of the equilibration peri-

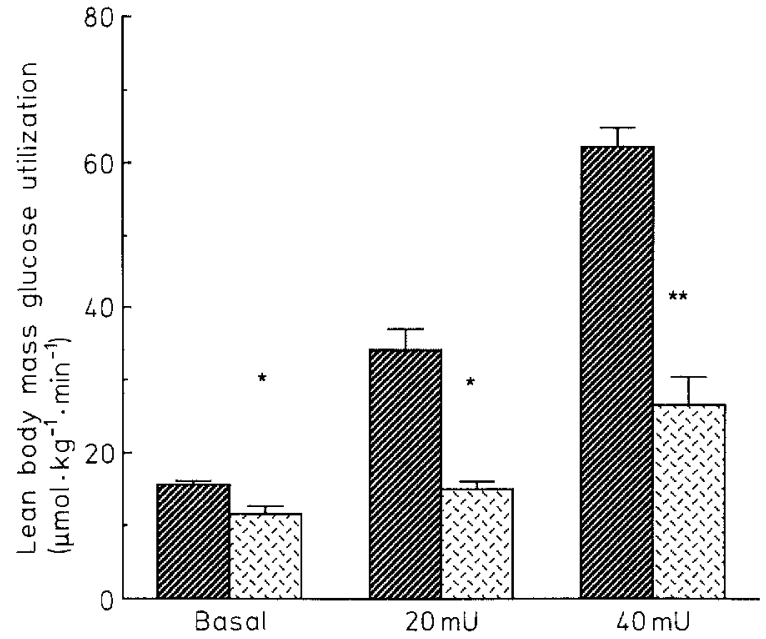

Fig. 1. Lean body mass glucose utilization $\left(\mu \mathrm{mol} \cdot \mathrm{kg} \mathrm{BM}^{-1} \cdot \mathrm{min}^{-1}\right)$ in the basal state and during euglycaemic stepwise insulin clamp $(20$ and $40 \mathrm{mU} \cdot \mathrm{m}^{2-1} \cdot \mathrm{min}^{-1}$ ) in normal weight (cross hatched bars) and obese individuals (stippled bars). $* p<0.05$, *** $p<0.001$

od as well as during the last half-hour of each insulin infusion step (coefficient of variation $<10 \%$ ). Therefore, a steady state condition was assumed during those time periods for calculation of plasma NEFA turnover. Since plasma NEFA are largely derived from lipolysis in adipose tissue [28], plasma NEFA turnover rate was normalized per unit $(\mathrm{kg})$ of FBM. On the other hand, plasma NEFA disposal is largely accounted for by lean body tissues [25, 29]. Therefore, plasma NEFA turnover rate was calculated per unit $(\mathrm{kg})$ of LBM.

Indirect calorimetry. Glucose and lipid oxidation rates were calculated from continuous measurement of gas exchanges [30] in the basal state, and during the last $40 \mathrm{~min}$ of each insulin infusion step. Non-oxidative glucose metabolism was computed as the difference between total glucose metabolism and glucose oxidation. The difference between plasma NEFA turnover rate and lipid oxidation was also calculated as an index of non-oxidative plasma NEFA metabolism $[31,32]$. All parameters are expressed per unit of LBM.

\section{Statistical analysis}

All data are presented as mean \pm SEM. The significance of difference between obese and control subjects was tested by Student's $t$-test and analyșis, of variance as appropriate [33]

\section{Results}

\section{Plasma insulin and glucose concentration}

Fasting plasma glucose concentration was similar in obese and control subjects $(4.7 \pm 0.3$ vs $4.4 \pm 0.2 \mathrm{mmol} / \mathrm{l})$. On the contrary, in obese individuals, basal plasma insulin concentration was threefold higher than in control subjects $(17 \pm 2$ vs $6 \pm 1 \mathrm{mU} / \mathrm{l} ; p<0.05$ ). During stepwise hyperinsulinaemia, euglycaemia was maintained in both groups ( $4.9 \pm 0.2$ vs $4.7 \pm 0.2 \mathrm{mmol} / \mathrm{l})$, with a coefficient of variation $<8 \%$. Plasma insulin concentration remained higher in obese patients during the stepwise insulin infusion $\left(20 \mathrm{mU} \cdot \mathrm{m}^{2-1} \cdot \mathrm{min}^{-1}=66 \pm 5\right.$ vs $36 \pm 2 \mathrm{mU} / 1 ; \quad 40 \mathrm{mU}$. $\mathrm{m}^{2-1} \cdot \min ^{-1}=102 \pm 7$ vs $70 \pm 3 \mathrm{mU} / 1 ;$ both $p<0.01$ ). 

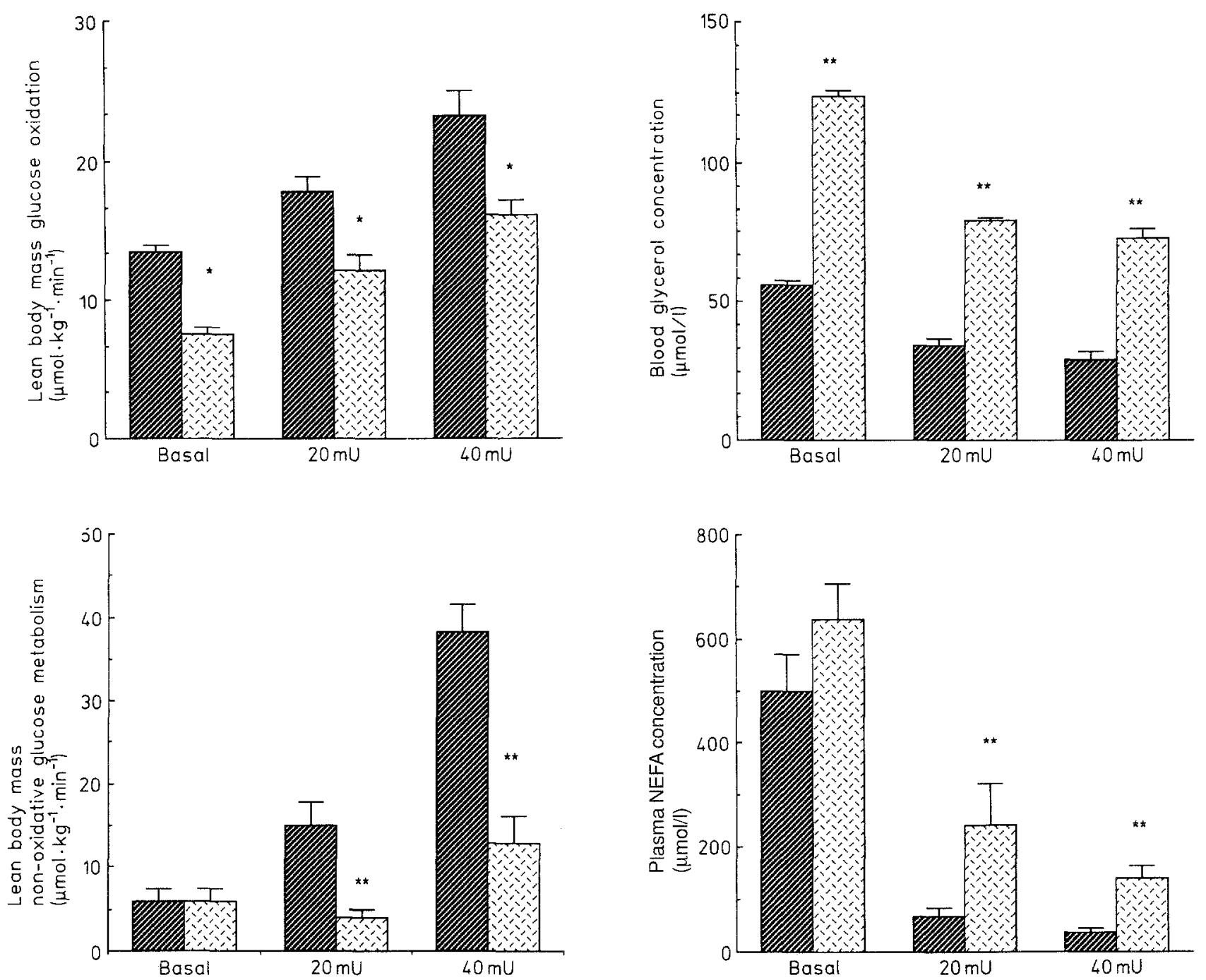

Fig. 2. Lean body mass oxidative (upper panel) and non-oxidative glucose metabolism (lower panel $\mu \mathrm{mol} \cdot \mathrm{kg} \mathrm{FBM}^{-1} \cdot \mathrm{min}^{-1}$ ) in the basal state and during euglycaemic stepwise insulin clamp (20 and $40 \mathrm{mU} \cdot \mathrm{m}^{2-1} \cdot \mathrm{min}^{-1}$ ) in normal weight (cross hatched bars) and obese individuals (stippled bars). * $p<0.05, * * p<0.001$

\section{Insulin-mediated glucose metabolism (Fig. 1 and 2)}

Basal glucose disposal was estimated by isotopic technique [31]. Fasting glucose utilization was significantly reduced in obese patients $\left(11.7 \pm 1.1 \mu \mathrm{mol} \cdot \mathrm{kg} \mathrm{LBM}^{-1}\right.$. $\min ^{-1}$ ) as compared to normal weight control subjects $\left(15.6 \pm 0.6 \mu \mathrm{mol} \cdot \mathrm{kg} \mathrm{LBM}{ }^{-1} \cdot \mathrm{min}^{-1} ; p<0.05 ;\right.$ Fig. 1$)$. In response to euglycaemic hyperinsulinaemia whole body glucose utilization increased in normal subjects to $34.4 \pm 2.8$ and $62.2 \pm 2.8 \mu \mathrm{mol} \cdot \mathrm{kg} \mathrm{LBM}{ }^{-1} \cdot \mathrm{min}^{-1}$ (Fig. 1). On the contrary, in spite of higher plasma insulin concentration, obese patients had a marked defect in the rate of insulinmediated glucose metabolism $(15.0 \pm 1.1$ and $26.7 \pm$ $3.9 \mu \mathrm{mol} \cdot \mathrm{kg} \mathrm{LBM}^{-1} \cdot \mathrm{min}^{-1}$ both $p<0.001$; Fig. 1$)$.

Total glucose disposal represents the sum of two ongoing processes: glucose oxidation and non-oxidative glucose metabolism. After overnight fasting, oxidative glucose metabolism was higher in normal subjects $(7.5 \pm 0.5$ vs $\left.13.5 \pm 0.5 \mu \mathrm{mol} \cdot \mathrm{kg} \mathrm{LBM}{ }^{-1} \cdot \mathrm{min}^{-1} ; p<0.01\right)$ whereas

Fig.3. Blood glycerol (upper panel) and plasma NEFA (lower panel) concentrations $(\mu \mathrm{mol} / \mathrm{l})$ in the basal state and during euglycaemic stepwise insulin clamp ( 20 and $40 \mathrm{mU} \cdot \mathrm{m}^{2-1} \cdot \mathrm{min}^{-1}$ ) in normal weight (cross hatched bars) and obese individuals (stippled bars). ** $p<0.001$

no difference was evident in the rate of non-oxidative glucose metabolism between the two groups $(6.0 \pm 1.5 \mathrm{vs}$ $6.1 \pm 1.3 \mu \mathrm{mol} \cdot \mathrm{kg} \mathrm{LBM}^{-1} \cdot \mathrm{min}^{-1}$; Fig. 2). Following insulin stimulation, the ability to oxidize glucose was markedly altered in obese patients both at the lower $\left(12 \pm 1.1\right.$ vs $\left.17.8 \pm 1.1 \mu \mathrm{mol} \cdot \mathrm{kg} \mathrm{LBM}{ }^{-1} \cdot \mathrm{min}^{-1} ; p<0.05\right)$ and the higher insulin infusion rate $(16.1 \pm 1.1$ vs $\left.23.3 \pm 1.7 \mu \mathrm{mol} \cdot \mathrm{kg} \mathrm{LBM}{ }^{-1} \cdot \mathrm{min}^{-1} ; p<0.001 ; \mathrm{Fig} .2\right)$. The stimulation of non-oxidative glucose metabolism appeared even more compromised in obese individuals $(20 \mathrm{mU}$ clamp $=3.9 \pm 1.1$ vs $15.0 \pm 2.8 ; 40 \mathrm{mU}$ clamp $=$ $12.8 \pm 3.3$ vs $38.3 \pm 3.3 \mu \mathrm{mol} \cdot \mathrm{kg} \mathrm{LBM}{ }^{-1} \cdot \min ^{-1} ; p<0.01-$ 0.001; Fig. 2).

\section{Hepatic glucose production}

After an overnight fast, the liver is the only site of glucose production in man. Its rate of glucose output is mainly regulated by portal insulin concentration and hepatic sen- 
sitivity to the hormone. Therefore, we have chosen to express HGP as the total amount of glucose produced by the liver in response to different plasma insulin concentrations. Total basal HGP was slightly higher in obese $(1.11 \pm 0.06 \mathrm{mmol} / \mathrm{min})$ than in normal weight subjects $(0.84 \pm 0.05 \mathrm{mmol} / \mathrm{min})$ in spite of the higher plasma insulin concentration. During the first euglycaemic insulin step, HGP in control individuals was suppressed by $>90 \%$ $(0.08 \pm 0.04 \mathrm{mmol} / \mathrm{min})$. This suppression became complete with the second plasma insulin plateau. In obese patients, HGP was not as well inhibited. During the $20 \mathrm{mU}$ insulin clamp HGP was in fact $0.36 \pm 0.02 \mathrm{mmol} / \mathrm{min}$ ( $p<0.05$ vs controls) and only during the second insulin infusion step was it completely suppressed.

\section{Insulin-mediated lipid metabolism (Table 2 and}

Figs. 3 and 4)

Fasting plasma NEFA concentrations were slightly higher in obese subjects $(635 \pm 75 \mu \mathrm{mol} / 1)$ than in control individuals $(510 \pm 71 \mu \mathrm{mol} / \mathrm{l})$. On the contrary, basal blood levels of glycerol were significantly increased $(129 \pm 17$ vs $56 \pm 5 \mu \mathrm{mol} / 1 ; p<0.01 ;$ Fig. 3 ). In normal subjects, euglycaemic hyperinsulinaemia was associated with a prompt and marked drop in plasma NEFA level $(20 \mathrm{mU}$ insulin clamp $=69 \pm 16 ; 40 \mathrm{mU}$ insulin clamp $=36 \pm 10 \mu \mathrm{mol} / \mathrm{l}$ ).

Plasma NEFA concentration fell in obese patients as well (Table 2). However, their plasma levels remained significantly higher than in normal individuals both during the first $(244 \pm 79 \mu \mathrm{mol} / \mathrm{l})$ and the second insulin infusion step $(140 \pm 25 \mu \mathrm{mol} / /$; both $p<0.01)$. Blood glycerol concentrations also were significantly higher in obese patients at each degree of euglycaemic hyperinsulinaemia (Fig. 3).

Basal plasma NEFA production rate from adipose tissue was markedly lower in obese patients $\left(14.0 \pm 1.8 \mu \mathrm{mol} \cdot \mathrm{kg} \mathrm{FBM}^{-1} \cdot \mathrm{min}^{-1}\right)$ than in normal subjects $\left(37.7 \pm 6.7 \mu \mathrm{mol} \cdot \mathrm{kg} \mathrm{FBM}^{-1} \cdot \mathrm{min}^{-1} ; p<0.05\right)$, and it was positively correlated with fasting plasma NEFA concentrations $(r=0.75 ; p<0.01)$. On the contrary, plasma
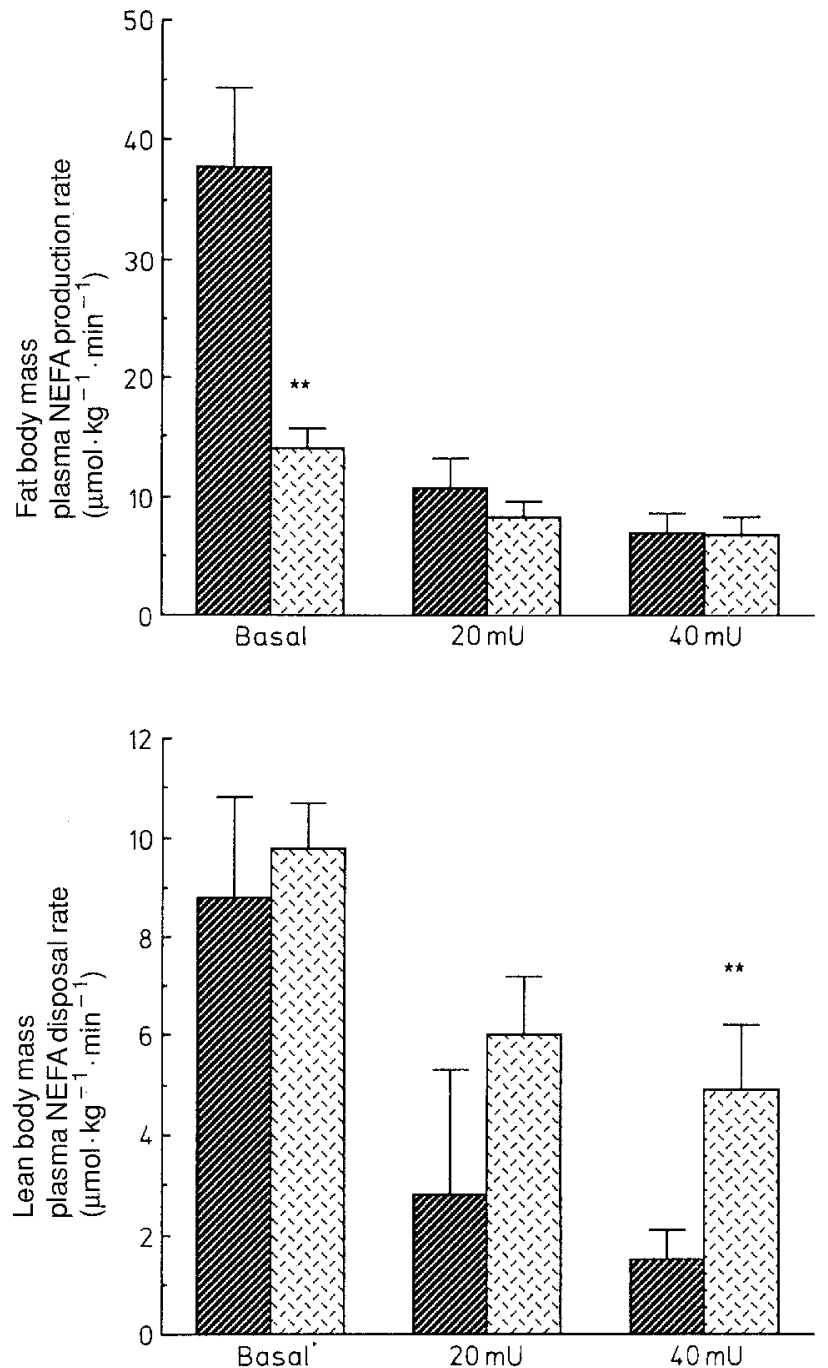

Fig.4. Fat body mass plasma NEFA production rate (upper panel) and lean body mass plasma NEFA disposal rate (lower panel; $\left.\mu \mathrm{mol} \cdot \mathrm{kg}^{-1} \cdot \mathrm{min}^{-1}\right)$ in the basal state and during euglycaemic stepwise insulin clamp (20 and $\left.40 \mathrm{mU} \cdot \mathrm{m}^{2-1} \cdot \mathrm{min}^{-1}\right)$ in normal weight (cross hatched bars) and obese individuals (stippled bars). ** $p<0.001$

Table 2. Lipid metabolism in obese and normal weight individuals in post-absorptive state and during euglycaemic stepwise insulin (20 and $\left.40 \mathrm{mU} \cdot \mathrm{m}^{2-1} \cdot \mathrm{min}^{-1} \mathrm{clamp}\right)$

\begin{tabular}{|c|c|c|c|c|c|c|}
\hline & \multicolumn{2}{|l|}{ Basal } & \multicolumn{2}{|c|}{$20 \mathrm{mU} \cdot \mathrm{m}^{2-1} \cdot \mathrm{min}^{-1}$} & \multicolumn{2}{|c|}{$40 \mathrm{mU} \cdot \mathrm{m}^{2-1} \cdot \mathrm{min}^{-1}$} \\
\hline & $\begin{array}{l}\text { Normal } \\
\text { subjects }\end{array}$ & $\begin{array}{l}\text { Obese } \\
\text { subjects }\end{array}$ & $\begin{array}{l}\text { Normal } \\
\text { subjects }\end{array}$ & $\begin{array}{l}\text { Obese } \\
\text { subjects }\end{array}$ & $\begin{array}{l}\text { Normal } \\
\text { subjects }\end{array}$ & $\begin{array}{l}\text { Obese } \\
\text { subjects }\end{array}$ \\
\hline $\begin{array}{l}\text { Blood glycerol } \\
(\mu \mathrm{mol} / \mathrm{l})\end{array}$ & $56 \pm 5$ & $129 \pm 17$ & $34 \pm 6$ & $79 \pm 20$ & $29 \pm 5$ & $73 \pm 22$ \\
\hline $\begin{array}{l}\text { Plasma NEFA utilization rate } \\
\left(\mu \mathrm{mol} \cdot \mathrm{kg} \mathrm{LBM}{ }^{-1} \cdot \mathrm{min}^{-1}\right)\end{array}$ & $8.8 \pm 2.0$ & $9.8 \pm 0.9$ & $2.8 \pm 2.5$ & $6.0 \pm 1.2$ & $1.5 \pm 0.6$ & $4.9 \pm 1.3^{\mathrm{a}}$ \\
\hline $\begin{array}{l}\text { Lipid oxidation } \\
\left(\mu \mathrm{mol} \cdot \mathrm{kg} \mathrm{LBM}^{-1} \cdot \min ^{-1}\right)\end{array}$ & $4.5 \pm 0.6$ & $4.9 \pm 0.4$ & $2.3 \pm 0.4$ & $3.7 \pm 0.3^{a}$ & $0.9 \pm 0.3$ & $2.4 \pm 0.4^{a}$ \\
\hline 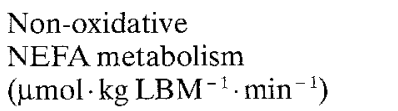 & $6.3 \pm 2.7$ & $4.6 \pm 0.7$ & $1.5 \pm 0.7$ & $2.1 \pm 1.1$ & $1.0 \pm 0.3$ & $2.6 \pm 1.0^{\mathrm{a}}$ \\
\hline
\end{tabular}


Table 3. Linear regression analysis of the rate of lipid oxidation and glucose oxidation, non-oxidative glucose metabolism, and whole glucose uptake

\begin{tabular}{|c|c|c|c|c|c|c|}
\hline & \multicolumn{6}{|c|}{ Lipid oxidation $\left(\mu \mathrm{mol} \cdot \mathrm{kg} \mathrm{LBM}^{-1} \cdot \mathrm{min}^{-1}\right)$} \\
\hline & \multicolumn{2}{|c|}{ Control subjects } & \multicolumn{2}{|c|}{ Obese subjects } & \multicolumn{2}{|c|}{ Control + obese subjects } \\
\hline & $r$ & $p<$ & $r$ & $p<$ & $r$ & $p<$ \\
\hline Glucose oxidation $^{\mathrm{a}}$ & -0.93 & 0.001 & -0.82 & 0.01 & -0.88 & 0.001 \\
\hline Non-oxidative glucose metabolism ${ }^{a}$ & -0.75 & 0.01 & -0.11 & NS & -0.61 & 0.001 \\
\hline Whole body glucose uptake ${ }^{a}$ & -0.83 & 0.001 & -0.54 & 0.05 & -0.75 & 0.001 \\
\hline
\end{tabular}

${ }^{\mathrm{a}} \mu \mathrm{mol} \cdot \mathrm{kg} \mathrm{LBM}{ }^{-1} \cdot \mathrm{min}^{-1} ; \mathrm{LBM}=$ Lean body mass

NEFA disposal rate was higher in obese $(20 \mathrm{mU}$ insulin clamp $=6.0 \pm 1.2 ; \quad 40 \mathrm{mU}=4.9 \pm 1.3 \mu \mathrm{mol} \cdot \mathrm{kg} \quad \mathrm{LBM}^{-1}$. $\left.\mathrm{min}^{-1}\right)$ than in normal weight subjects $(2.8 \pm 2.5$ and $1.5 \pm 0.6 \mu \mathrm{mol} \cdot \mathrm{kg} \mathrm{LBM}{ }^{-1} \cdot \mathrm{min}^{-1}$ respectively; $p<0.01-$ $0.05)$. No difference was found in basal $(17.0 \pm 1.7$ vs $\left.18.1 \pm 5.2 \mathrm{ml} \cdot \mathrm{kg} \mathrm{LBM}^{-1} \cdot \mathrm{min}^{-1}\right)$ as well as insulin-stimulated clearance rates $(20 \mathrm{mU}$ clamp $=23.6 \pm 3.9$ vs $35 \pm 13$; $40 \mathrm{mU}$ clamp $=32.8 \pm 7.7$ vs $35.7 \pm 14.3 \mathrm{ml} \cdot \mathrm{kg} \mathrm{LBM}^{-1}$. $\left.\min ^{-1}\right)$.

Lipid oxidation was measured by indirect calorimetry. In obese patients, basal values $(4.9 \pm 0.4 \mu \mathrm{mol} \cdot \mathrm{kg}$ $\left.\mathrm{LBM}^{-1} \cdot \mathrm{min}^{-1}\right)$ were similar to normal subjects $\left(4.5 \pm 0.6 \mu \mathrm{mol} \cdot \mathrm{kg} \mathrm{LBM}^{-1} \cdot \mathrm{min}^{-1} ; p=\right.$ N. S.). During euglycaemic hyperinsulinaemia, lipid oxidation was higher in obese patients $\left(3.7 \pm 0.3\right.$ and $2.4 \pm 0.4 \mu \mathrm{mol} \cdot \mathrm{kg} \mathrm{LBM}^{-1}$. $\mathrm{min}^{-1}$ at the two insulin infusions respectively) than in normal individuals $(2.3 \pm 0.4$ and $0.9 \pm 0.3 \mu \mathrm{mol} \cdot \mathrm{kg}$ $\left.\mathrm{LBM}^{-1} \cdot \min ^{-1} ; p<0.05-0.02\right)$. Non-oxidative metabolism of plasma NEFA was calculated as the difference between the rate of plasma NEFA utilization (obtained by tracer technique) and lipid oxidation (as measured by indirect calorimetry). The results are shown in Table 2 . Though no difference was evident in the basal state $(4.6 \pm 0.7$ vs $6.3 \pm 2.7 \mu \mathrm{mol} \cdot \mathrm{kg} \mathrm{LBM}{ }^{-1} \cdot \mathrm{min}^{-1} ; p=\mathrm{N}$. S.), during euglycaemic hyperinsulinaemia, non-oxidative plasma NEFA metabolism was increased in obese patients $(2.1 \pm 1.1$ vs $1.5 \pm 0.7$ and $2.6 \pm 1.0$ vs $1.0 \pm 0.3 \mu \mathrm{mol} \cdot \mathrm{kg} \mathrm{LBM}^{-1}$. $\left.\min ^{-1}\right)$.

\section{Glucose and lipid metabolism interaction}

Table 3 reports the results of regression analysis between the rate of lipid oxidation and different parameters of glucose metabolism over the range of physiological plasma insulin concentrations explored in this study. The rate of glucose oxidation was inversely correlated to the rate of lipid oxidation both in normal weight $(r=-0.93)$ and obese individuals $(r=-0.82)$. On the contrary, lipid oxidation correlated to the rate of non-oxidative glucose metabolism in normal individuals $(r=-0.75)$ but in obese patients $(r=-0.11)$. Still, if all data are pooled together, a significant negative correlation emerged $(r=-0.61)$. As a consequence of the relationship occurring between lipid oxidation and the two main pathways of glucose metabolism, the former was also related to the rate of whole body glucose disposal $(r=-0.83$ and -0.54 in normal weight and obese individuals, respectively; see Table 3 for significance levels).

\section{Discussion}

In our study we have employed the glucose clamp technique in combination with radioisotopic methods and simultaneous gas exchange measurements to evaluate insulin action on glucose and lipid metabolism in patients with massive obesity.

In agreement with a wealth of other studies $[1,2]$ using a similar approach, we have demonstrated that in nondiabetic obese subjects, insulin-mediated glucose metabolism is markedly altered. In response to two physiological degrees of hyperinsulinaemia, glucose disposal was $55 \%$ lower than in normal weight individuals. Impairment in glucose utilization was apparent in spite of plasma insulin concentrations that were higher in the basal state as well as during insulin infusion.

All tissues of the body (namely muscle, liver, and adipose tissues) seem to contribute to the condition of insulin resistance. In the presence of euglycaemic hyperinsulinaemia, lean body tissues (i.e. muscle) are primarily responsible for glucose disposal [34]. Normalization of glucose utilization per unit of lean body mass, clearly gives evidence for the primary insensitivity of these tissues to insulin (Fig. 1). Even though adipose tissue is believed to contribute no more than $1-2 \%$ to overall glucose disposal under the circumstance of the glucose clamp [35], it is possible that it may represent a site of insulin resistance as well. If one assumes a $2 \%$ glucose disposal by the whole body [36], it can be calculated that adipose tissue of obese patients was utilizing $0.44 \pm 0.06$ and $0.78 \pm 0.39 \mu \mathrm{mol} \cdot \mathrm{kg}$ $\mathrm{FBM}^{-1} \cdot \mathrm{min}^{-1}$ during two steps of hyperinsulinaemia respectively. The corresponding figures for normal weight individuals would be $0.78 \pm 0.11$ and $4.72 \pm 0.39 \mu \mathrm{mol} \cdot \mathrm{kg}$ $\mathrm{FBM}^{-1} \cdot \min ^{-1}(p<0.01)$. Although, such a calculation is loaded with assumptions, the difference looks so large as to be considered of some physiologic interest.

In the basal state, following a 10-12 h overnight fast, plasma glucose concentration was similar in obese and control subjects. Basal HGP was even greater in obese individuals. This occurred at the expense of plasma insulin concentrations that were threefold higher in obese patients than in control subjects, suggesting that the liver was insensitive to insulin. This condition becomes even more apparent following elevation of plasma insulin concentration. Whereas in normal subjects HGP was inhibited by $>85 \%$ at the lowest insulin plateau, in obese patients even higher insulin levels could not normally suppress HGP. This observation is striking if one considers that, in normal individuals, an increment as low as $10 \mathrm{mU} / \mathrm{l}$ in 
plasma insulin concentration reduces HGP by $70 \%$ [51]. In our obese patients a similar effect ( $68 \%$ inhibition) was obtained only in the presence of $66 \mathrm{mU} / \mathrm{l}$ plasma insulin concentration (Fig. 3).

The mechanism(s) responsible for the defect in insulin action remain to be elucidated. By means of indirect calorimetry we show that intracellular mechanisms are markedly altered in obese patients (Fig. 2). It is of note that, even though both oxidation and non-oxidative glucose metabolism are impaired, the latter is largely responsible for reduced glucose utilization (Fig.2). This finding goes along with the observation that glycogen-synthase is reduced in obese patients [37]. This, in combination with the knowledge that lean tissues account for the majority of glucose disposal, indicates that glycogen deposition in muscle is primarily involved in insulin resistance of obese patients.

In recent years, a metabolic mechanism has been invoked to account for at least part of insulin resistance in obesity $[38,39]$. This theory is based on the original observation of Randle et al. [12] that an NEFA glucose cycle exists according to which NEFA oxidation inhibits glucose oxidation and ultimately glucose utilization itself. Plasma NEFA concentrations are often increased in obese patients [3, 4]. In this particular set of obese patients, the fasting plasma NEFA level was only slightly increased in comparison to normal weight subjects. Similarly, we could not report a significant increase in basal plasma NEFA turnover rate (Table 2). It is of note that such a "normal" plasma NEFA metabolism occurs in the presence of marked hyperinsulinaemia, suggesting that either higher insulin concentrations are required to restrain excessive NEFA release from fat depots or that the circulating NEFA levels are sufficient to meet the energy requirement to feed back on the rate of lipolysis [41]. The evidence that the rate of NEFA release is lower in obese patients than in control subjects (Fig. 4) would support the former hypothesis. Furthermore, this might imply a normal insulin action on lipolysis and stress the importance of the amount of adipose tissue in the alteration of NEFA metabolism. This interpretation is apparently supported by the finding that the absolute rate of NEFA production during hyperinsulinaemia in obese patients is equal to control subjects. Since plasma NEFA utilization is increased in these patients (Fig. 4), the only apparent cause for sustained plasma NEFA concentration during the clamp studies is the massively enlarged adipose data. Though the rate of plasma NEFA production is quantitatively similar in obese and control individuals during euglycaemic hyperinsulinaemia, the percent reduction $(-41$ and $-53 \%$ vs -74 and $-82 \%$ at the two insulin plateaus respectively) is significantly $(p<0.05)$ reduced in the former suggesting a defect in insulin action on adipose tissue. This interpretation is supported by the sustained elevation in blood glycerol concentration in the basal state as well as following euglycaemic hyperinsulinaemia found in obese individuals (Fig. 3).

In both normal and obese subjects, a maximal reduction of blood glycerol was obtained with the lower insulin infusion rate. In contrast, plasma NEFA concentration was further reduced during the higher insulin infusion rate. Such a result may suggest a different insulin sensitivity for glycerol and NEFA metabolism. This might be explained by a stimulation of intracellular NEFA reesterification secondary to increased availability of alpha-glycerolphosphate derived from insulin-stimulated glucose metabolism at the level of the adipose tissue. On the other hand, a drop in blood glycerol concentration in response to a further increment in plasma insulin concentration might be prevented by an increased conversion of glucose to glycerol [42]. Therefore, the explanation for the different effect of euglycaemic hyperinsulinaemia on glycerol and NEFA metabolism cannot be drawn in the absence of kinetic analysis of glycerol turnover.

During euglycaemic insulin clamp, plasma NEFA concentrations remained higher in obese patients (Table 2). The rate of plasma NEFA utilization is a function of their prevalent concentration [41, 43]. In agreement with this, plasma NEFA disposal rate was higher in obese individuals (Table 2). This result, in combination with the finding that the clearance rate of plasma NEFA was not altered in obese patients also supports the main role for increased lipolysis in maintaining high plasma NEFA levels.

In conclusion, it is likely that larger adipose tissue as well as insulin resistance can contribute to alteration in plasma NEFA metabolism in massive obese patients.

Plasma NEFA disposal is the sum of two ongoing processes: oxidation and reesterification. As already recalled, the rate of plasma NEFA utilization and oxidation $[41,43]$ are strictly dependent upon prevalent plasma NEFA levels. We have no direct measurement of plasma NEFA oxidation. However, lipid oxidation as measured by means of gaseous exchange is largely accounted for by oxidation of circulating NEFA [39]. It is apparent from Table 2 that the higher the plasma NEFA levels and the production rate of plasma NEFA, the higher the lipid oxidation rate. Furthermore, it is of note that the \% of plasma NEFA utilization rate that can be accounted for by lipid oxidation was similar in obese and normal weight subjects and was not significantly affected by a change in the plasma insulin concentration (obese subjects $=44 \pm 6 ; 73 \pm 10$; and $61 \pm 17 \%$; normal subjects $=52 \pm 13 ; 70 \pm 13$; and $46 \pm 13 \%$ at baseline, and during 20 , and $40 \mathrm{mU} / \mathrm{m}^{2} \cdot \mathrm{min}$ insulin clamp, respectively; $p=$ NS vs basal and between groups). This finding also suggests that plasma NEFA concentration can directly modulate both oxidative and non-oxidative metabolism (Table 2). In the present study, we found an inverse correlation between lipid and glucose oxidation, both in normal weight $(r=-0.93)$ and in obese individuals $(r=-0.88$, both $p<0.001)$. This relationship is in keeping with the Randle cycle [12] and in agreement with the results of Lillioja et al. [31]. These authors however, could not find any correlation between the rate of lipid oxidation and non-oxidative glucose metabolism. In their paper, they suggested that a separate regulation of oxidative and non-oxidative pathways [44] or an earlier saturation of glucose oxidation as compared to glycogen deposition [45], could be a likely explanation for such a dichotomy. In our study, we failed also to detect a correlation between lipid oxidation and non-oxidative glucose metabolism in obese subjects (Table 3). Nevertheless, a highly significant correlation existed in normal individuals 
$(r=-0.75, p<0.01)$. This can be explained by the fact that we used a plasma insulin concentration that does not lead to complete saturation of the processes involved in glucose oxidation and, more importantly, that obese patients do have an intrinsic alteration in glucose metabolism that goes beyond the simple effect of an increased rate of lipid oxidation. This interpretation fits with the knowledge that non-oxidative glucose metabolism is, from a quantitative point of view, largely responsible for the defect in glucose disposal (Fig.2) and that specific enzymatic defects in glycogen synthesis have been reported in subjects with obesity [38]. It is, however, of note that the increased rate of lipid oxidation, in some way, contributes to reduced glucose utilization (Table 3). Much evidence supports the hypothesis that increased lipid oxidation may play a distinctive role in insulin resistance states [11, 46]. Meylan et al. [38] have recently demonstrated that inhibition of lipolysis by nicotinic acid in obese patients can reverse glucose intolerance and reduce the hyperinsulinaemic response to oral glucose load. However, these results do not solve the problem of whether or not the alteration in NEFA metabolism is primary or secondary (i.e. secondary to reduced glucose utilization in adipose tissue). The two hypotheses may be unified into one whereby, once obesity is settled, a reduction in glucose disposal develops in all tissues of the body through insulin receptor down-regulation, alteration in glucose transport carriers, or some other still undefined mechanism(s). The involvement of adipose tissue may result in a reduction in intracellular NEFA re-esterification with subsequent increased NEFA release into the bloodstream. Elevated plasma NEFA concentration leads to increased plasma NEFA utilization, increased plasma NEFA oxidation, inhibition of glucose oxidation and reduced glucose uptake. The latter may then reactivate the vicious cycle until possible development of impaired glucose tolerance or overt diabetes as soon as a defect in insulin secretion intervenes.

Acknowledgements. We thank Ms. E. Duner, Ms. C. Marescotti, and Ms. A. Valerio for their laboratory assistance. We also thank Mr. V. Gerunda for preparation of figures and Ms. R. Wolfe for her secretarial help. This study was supported by CNR grant N. 84.01840.04.

\section{References}

1. Garvey WT, Kolterman OG (1988) Correlation of in vivo and in vitro actions in obesity and non-insulin-dependent diabetes mellitus: role of the glucose transport system. Diab Metab Rev 4: 543-570

2. Kissebah AH, Freedman DS, Peiris AN (1989) Health risks of obesity. Med Clin N Am 73: 111-138

3. Gorden ES (1960) Non-esterified fatty acids in the blood of obese and lean subjects. Am J Clin Nutr 8: 740-747

4. Opie LH, Walfish PG (1963) Plasma free fatty acid concentrations in obesity. $N$ Engl J Med 268: 756-760

5. Arner P, Bolinder J, Engfeldt P, Ostman J (1981) The antilipolytic effect of insulin in human adipose tissue in obesity, diabetes mellitus, hyperinsulinaemia and starvation. Metbolism 30: $753-760$

6. Rabinowitz B, Zierler KL (1962) Forearm metabolism in obesity and its response to intraarterial insulin. J Clin Invest 41 : 2173-2181
7. Howard B, Savage PJ, Nagulesparan M, Bennion LJ, Unger RH, Bennett PH (1979) Evidence for marked sensitivity to the antilipolytic action of insulin in obese maturity onset diabetes. Metabolism 28: 744-751

8. Howard B, Klimies J, Vasquez B, Brady D, Nagulesparan M, Unger RH (1984) The antilipolytic action of insulin in obese subjects with resistance to its glucoregulatory action. J Clin Endocrinol Metab 58: 544-551

9. Bakir SM, Jarret RJ (1981) The effects of low dose insulin infusion upon plasma glucose and non-esterified fatty acid levels in very obese and non obese human subjects. Diabetologia 20: 592-596

10. Nestel PJ, Ishikawa T, Goldrik R (1978) Diminished plasma free fatty acid clearance in obese subjects. Metabolism 27:589-597

11. Ferrannini E, Barret E, Bevilacqua S, DeFronzo RA (1983) Effect of fatty acids on glucose production and utilization in man. J Clin Invest 72: 1737-1747

12. Randle PJ, Garland PB, Hales CN, Newsholme EA (1963) The glucose-fatty acid cycle. Its role in insulin sensitivity and the metabolic disturbances of diabetes mellitus. Lancet I: 785-789

13. Hume R, Weyers E (1971) Relationship between total body water and surface area in normal and obese subjects. J Clin Path 24: $234-238$

14. National Diabetes Data Group (1979) Classification and diagnosis of diabetes mellitus and other categories of glucose intolerance. Diabetes 28: 1039-1057

15. DeFronzo RA, Tobin D, Andres R (1979) Glucose clamp technique: a method for quantifying insulin secretion and resistance. Am J Physiol 273: E214-E223

16. Del Prato S, Nosadini R, Tiengo A, Tessari P, Avogaro A, Trevisan R, Valerio A, Muggeo M, Cobelli C, Toffolo G (1983) Insulin-mediated glucose disposal in type 1 diabetes: evidence for insulin resistance. J Clin Endocrinol Metab 57: 904-910

17. Ferrannini E, Del Prato S, DeFronzo RA (1986) Glucose kinetics. Tracer methods. In: Clarke WZ, Larner J, Pohl SL (eds) Methods in diabetes research, Vol II. Wiley, New York, pp 107142

18. Herbert V, Lan K, Gottlieb CW, Bleichner SH (1965) Coated charcoal immunoassay of insulin. J Clin Endocrinol Metab 25: $1375-1384$

19. Hawk PD (1947) Kjeldahl method. In: Practical physiological chemistry, 12th edn. Blakiston, Toronto, pp 814822

20. Dole VP (1956) A relation between non esterified fatty acids in plasma and the metabolism of glucose. J Clin Invest 35: 151-154

21. Pace N, Rathbun EN (1945) Studies on body composition. III. The body water and chemically combined nitrogen content in relation to fat content. J Biol Chem 158: 685-691

22. Del Prato S, Ferrannini E, DeFronzo RA (1986) Evaluation of insulin sensitivity in man. In: Clarke WKL, Larner J, Pohl S (eds) Methods in diabetes research, Vol II. Wiley, New York, pp 35-76

23. De Fronzo RA, Ferrannini E (1987) Regulation of hepatic glucose metabolism in humans. Diab Metab Rev 3: 415-459

24. Gottesman I, Mandarino L, Gerich J (1983) Estimation and kinetic analysis of insulin-independent glucose uptake in human subjects. Am J Physiol 244: E632-E635

25. Hagenfeldt L, Wahren J, Pernow B, Raf L (1982) Uptake of individual free fatty acids skeletal muscle and liver in man. J Clin Invest 51:2324-2330

26. Hagenfeldt L (1975) Turnover of individual free fatty acids in man. Fed Proc 34: 2246-2251

27. Owen OE, Trapp VE, Reichard GA, Mozzoli MA, Moctezuma J, Paul P, Skutches CL, Boden G (1983) Nature and quantity of fuels consumed in patients with alcoholic cirrhosis. J Clin Invest $72: 1821-1832$

28. Newsholme EA, Start C (1973) Adipose tissue and the regulation of fat metabolism. In: Newsholme EA, Stuart C (eds) Regulation in metabolism. Wiley, London New York, pp 214-223

29. Bragdon JH, Gordon RS (1958) Tissue distribution of C14 after the intravenous injection of labelled chylomicrons and unesterified fatty acids in the rat. J Clin Invest 37: 574-578 
30. Ferrannini E (1988) The theoretical basis of indirect calorimetry: a review. Metabolism 37: 287-301

31. Lillioja S, Foley J, Bogardus C, Mott D, Howard BV (1986) Free fatty acid metabolism in obesity in man: in vitro and in vivo comparison. Metabolism 35: 515-514

32. Taskinen M-R, Bogardus C, Kennedy A, Howard BV (1985) Multiple disturbances of free fatty acid metabolism in noninsulin-dependent diabetes. Effect of oral hypoglycemic therapy. J Clin Invest 76: 637-644

33. Snedecor GW, Cochran WG (1967) Statistical methods, 6th edn. Iowa State University Press, Ames, IA

34. DeFronzo RA, Jacot E, Jequier E, Maeder E, Wahren J, Felber JP (1981) The effect of insulin on the disposal of intravenous glucose. Results from indirect calorimetry and hepatic and femoral catheterization. Diabetes 30: 1000-1007

35. Bjorntorp R, Sjostrom (1978) Carbohydrate storage in man: speculations and quantitative considerations. Metabolism 27 (Suppl 2): 1853-1865

36. Groop L, Bonadonna R, Del Prato S, Ratheiser K, Zyck K, Ferrannini E, De Fronzo RA (1989) Glucose and free fatty acid metabolism in non-insulin dependent diabetes mellitus: evidence for multiple sites of insulin resistance. J Clin Invest 84: 205-213

37. Evans DJ, Murray R, Kissebah AH (1984) Relationship between skeletal muscle insulin resistance, insulin-mediated glucose disposal and insulin binding. Effect of obesity and body fat topography. J Clin Invest 74: 1515-1525

38. Meylan M, Henny C, Temler E, Jequier E, Felber JP (1987) Metabolic factors in the insulin resistance in human obesity. Metabolism 36: 256-261

39. Lillioja S, Bogardus C, Mott MD, Kennedy L, Knowler WC, Howard BW (1985) Relationship between insulin mediated glucose disposal and lipid metabolism in man. J Clin Invest 75: 11061115

40. Wolfe RR, Peters EJ, Klein S, Holland OB, Rosenblatt J, Gary H (1987) Effect of short-term fasting on lipolytic respon- siveness in normal and obese human subjects. Am J Physiol 252: E189-E196

41. Issekutz BP, Paul P, Miller HI, Bortz P (1986) Oxidation of plasma FFA in lean and obese humans. Metabolism 17:62-73

42. Nurjhan N, Campbell PJ, Kennedy FP, Miles JM, Gerich JE (1986) Insulin dose-response characteristics for suppression of glycerol release and conversion to glucose in humans. Diabetes 35: $1326-1331$

43. Miles JM, Haymond MW, Nissen S, Gerich J (1983) Effects of free fatty acid availability, glucagon excess and insulin deficiency on ketone body production in post-absorptive man. J Clin Invest 71: 1554-1561

44. Felber JP, Meyer H, Curchod B, Iselin HU, Rouselle J, Maeder E, Pahud P, Jequier E (1981) Glucose storage and oxidation in different degrees of human obesity measured by continuous indirect calorimetry. Diabetologia 21:39-44

45. Thiebaud D, Jacot E, DeFronzo RA, Maeder E, Jequier E, Felber JP (1982) The effect of graded doses of insulin on total glucose uptake, glucose oxidation and glucose storage in man. Diabetes 31: 957-963

46. Vigili de Kreutzenberg S, Lisato G, Riccio A, Giunta F, Bonato M, Petolillo M, Tiengo A, Del Prato S (1988) Metabolic control during total parenteral nutrition: use of an endocrine pancreas. Metabolism 37:510-513

Received: 21 November 1988

and in final revised form: 9 November 1989

Dr. S. Del Prato

Cattedra di Malattie del Ricambio

Via Giustiniani, 2

I-35128 Padova

Italy 